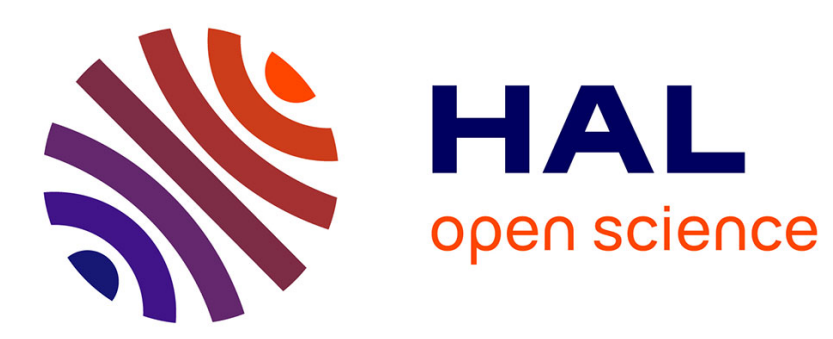

\title{
Diagnostic yield of lumbar puncture in adult patients with purpura fulminans
}

Damien Contou, Romain Sonneville, Armand Mekontso Dessap, Nicolas de Prost, Samir Jaber

\section{- To cite this version:}

Damien Contou, Romain Sonneville, Armand Mekontso Dessap, Nicolas de Prost, Samir Jaber. Diagnostic yield of lumbar puncture in adult patients with purpura fulminans. Intensive Care Medicine, $2019,10.1007 / \mathrm{s} 00134-019-05676-0$. hal-02176085

\section{HAL Id: hal-02176085 \\ https://hal.science/hal-02176085}

Submitted on 19 May 2020

HAL is a multi-disciplinary open access archive for the deposit and dissemination of scientific research documents, whether they are published or not. The documents may come from teaching and research institutions in France or abroad, or from public or private research centers.
L'archive ouverte pluridisciplinaire HAL, est destinée au dépôt et à la diffusion de documents scientifiques de niveau recherche, publiés ou non, émanant des établissements d'enseignement et de recherche français ou étrangers, des laboratoires publics ou privés. 


\title{
Diagnostic yield of lumbar puncture in adult patients with purpura fulminans
}

\author{
Damien Contou ${ }^{1,2^{*}}$, Romain Sonneville ${ }^{3}$, Armand Mekontso Dessap ${ }^{2,4}$, Nicolas de Prost ${ }^{2,4}$ and For the \\ HOPEFUL study group
}

\section{Dear Editor,}

Purpura fulminans (PF) is a rare infection mainly affecting young and otherwise healthy patients $[1,2]$. It carries high mortality $[1,2]$ and morbidity rates [3]. Microbiological documentation is obtained in more than $90 \%$ of cases [1], with Neisseria meningitidis and Streptococcus pneumoniae found to be the main responsible bacteria [1]. It remains to be established whether lumbar puncture (LP) should be performed in adult patients with PF. LP may be useful for optimizing bacteriological documentation or for adjusting the dose of $\beta$-lactam antibiotics in cases of associated meningitis. However, most of these patients have no consciousness disorders [1], and other less invasive sampling methods such as blood cultures or skin biopsy $[1,4]$ may be sufficient to isolate the causative bacterium. Moreover, LP may be contra-indicated due to the presence of severe thrombocytopenia [1] and coagulation disorders [1], which are almost constant findings in patients with PF. Our aim was to evaluate the diagnostic yield of LP in adult patients with PF.

We performed an ancillary analysis of a 17-year multicenter retrospective cohort study that included adult patients admitted to the ICU for infectious PF. The methods and patients have been previously described elsewhere [1] (online supplement). LP was performed at the discretion of the intensivist. LP was considered contributive when it showed meningitis (defined as ten or more white blood cells $/ \mathrm{mm}^{3}$ of cerebrospinal fluid, CSF)

\footnotetext{
*Correspondence: damien.contou@ch-argenteuil.fr

${ }^{1}$ Service de réanimation polyvalente, Centre Hospitalier Victor Dupouy, 69, rue du Lieutenant-Colonel Prud'hon, 95100 Argenteuil, France Full author information is available at the end of the article
}

and/or when a CSF bacterial culture was positive and/or when a PCR in CSF was positive for N. meningitidis or S. pneumoniae. All patients had blood cultures upon ICU admission, but skin biopsy was not routinely performed.

Among the 306 patients admitted for PF (median Glasgow Coma Scale score 15 [1st-3rd quartiles 13-15]), 171 (56\%) had an LP upon ICU admission. A comparison between the patients submitted to and those not submitted to LP is available in eTable 1. Cerebral CT scan was performed before LP in 21/171 (12\%) patients. CSF analysis revealed meningitis in $61 / 149$ (41\%) patients (CSF count was missing in the other 22 patients), while bacterial culture was positive in 85/171 (50\%). Notably, 37/88 (42\%) patients without cytological meningitis, and 41/121 (34\%) patients with negative CSF Gram stain eventually had a positive CSF culture. Among the 73 patients with no cytological meningitis and a negative CSF Gram stain, 23 (32\%) had a positive CSF culture. A comparison between patients with and those without contributive LP is provided in eTable 2. Factors independently associated with contributive LP were identified by uni- and multivariable logistic regression, and were as follows: age $<30$ years (adjusted odds ratio $(\mathrm{aOR})=3.45$ [1.67-7.12]; $p=0.001)$ and a Glasgow Coma Scale score $\leq 13(\mathrm{aOR}=7.56$ [2.71-12.10]; $p<0.0001)$ (eTable 3). A sensitivity analysis in which contributive LP was defined as five [5] or more white blood cells $/ \mathrm{mm}^{3}$ of CSF did not alter these findings (eTable 4). The rate of microbiological documentation did not differ between patients who underwent an LP and those who did not $(n=161 / 171$ (94\%) vs. $n=127 / 135$ (94\%); $p>0.99$ ) (Fig. 1, eTable 1). Antibiotic therapy administered before ICU admission did not alter the global rate of microbiological documentation ( $n=218 / 230(95 \%)$ vs. $n=70 / 76(92 \%), p=0.403)$ or the rate of positive CSF cultures $(n=71 / 136(52 \%)$ vs. 


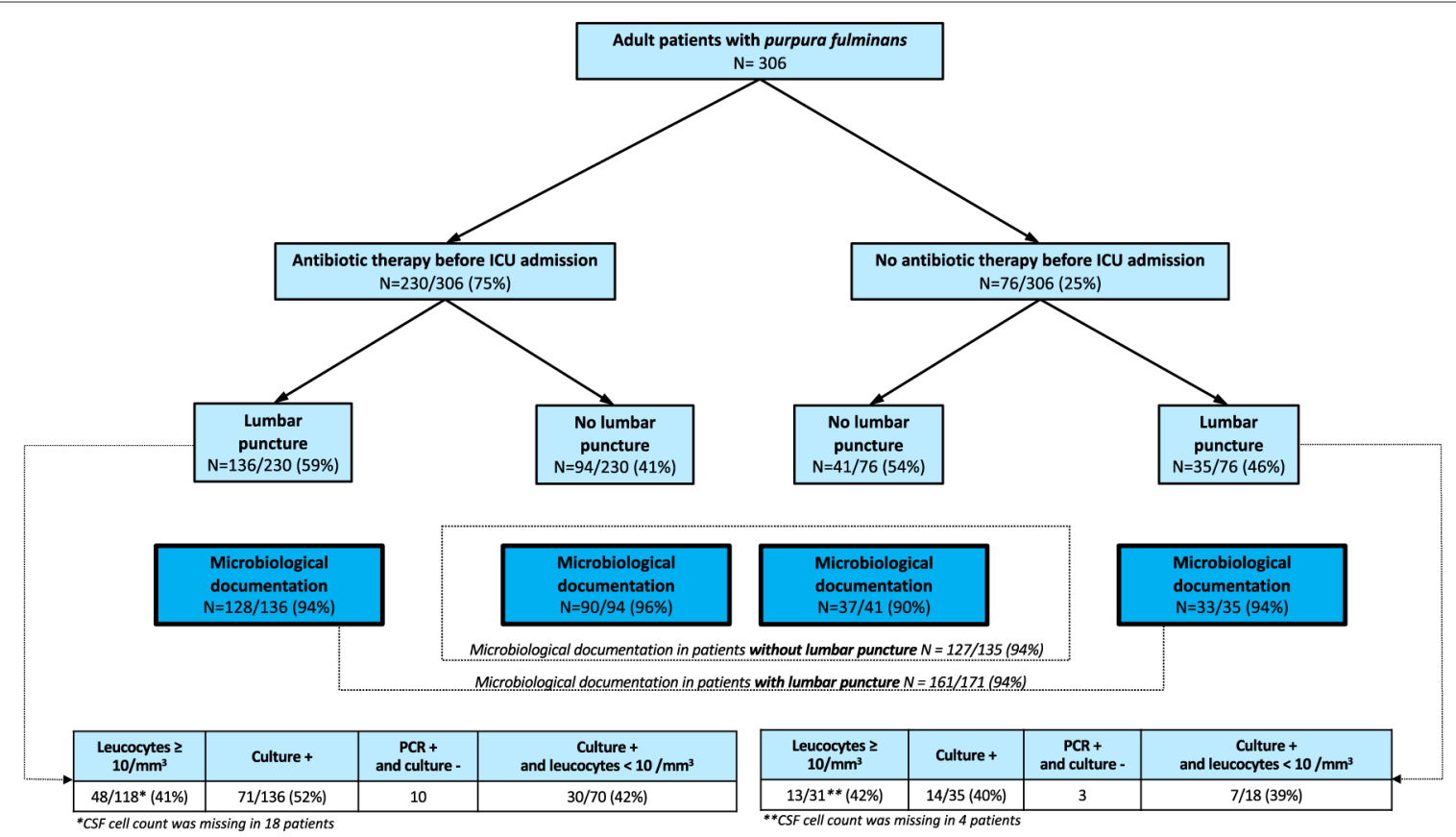

Fig. 1 Global microbiological documentation (including skin biopsies, blood and CSF cultures, and PCR for N. meningitidis or S. pneumoniae) and results of lumbar puncture in adult patients with purpura fulminans $(n=306)$ who received $(n=230)$ or did not receive $(n=76)$ antibiotic therapy before ICU admission

$n=14 / 35$ (40\%), $p=0.256$ ) (Fig. 1). CSF bacterial culture was the only positive microbiological test in $41 / 306(13 \%)$ patients (eFigure 1). Four brain deaths related to cerebral herniation and one post-LP headache were reported in patients submitted to LP. No paraplegia related to epidural hematoma or bleeding at the site of LP was reported.

Performing an LP did not significantly increase the rate of microbiological documentation in adult patients with PF, whether or not the patient had received antibiotic therapy before ICU admission. The bacteriological yield of LP appears to be limited a fortiori in a context where skin biopsy might be extensively performed [4]. In the absence of contra-indications (i.e., severe thrombocytopenia, coagulation disorders, and profound consciousness disorders/focal motor deficit, unless a CT scan has been performed and shows no major intracranial abnormality), recourse to LP may be considered for diagnosing associated meningitis/neuro-meningeal bacterial seeding, and adjusting the dose of $\beta$-lactam antibiotics, particularly in patients younger than 30 years old or presenting consciousness disorders. In view of the retrospective design of the present study, the fact that the decision to perform an LP was left to the discretion of the intensivist, and the absence of systematic skin biopsy and PCR results, our data have to be interpreted with caution and a general recommendation cannot be given.
Electronic supplementary material

The online version of this article (https://doi.org/10.1007/s00134-019-05676-0) contains supplementary material, which is available to authorized users.

\section{Author details}

1 Service de réanimation polyvalente, Centre Hospitalier Victor Dupouy, 69, rue du Lieutenant-Colonel Prud'hon, 95100 Argenteuil, France. ${ }^{2}$ Groupe de recherche clinique CARMAS, Université Paris Est Créteil, Créteil, France. ${ }^{3}$ Service de réanimation médicale, Hôpital Bichat-Claude Bernard, Assistance Publique-Hôpitaux de Paris, 46, rue Henri Huchard, 75877 Paris Cedex 18, France. ${ }^{4}$ Service de réanimation médicale, Hôpital Henri Mondor, Assistance Publique-Hôpitaux de Paris, 51 Avenue du Maréchal de Lattre de Tassigny, 94000 Créteil, France.

\section{Acknowledgements}

HOPEFUL study group: Laurent Argaud (Lyon), François Barbier (Orléans), Amélie Bazire (Brest), Gaëtan Béduneau (Rouen), Frédéric Bellec (Montauban), Pascal Beuret (Roanne), Pascal Blanc (Pontoise), Cédric Bruel (Saint-Joseph, Paris), Christian Brun-Buisson (Mondor, AP-HP), Gwenhaël Colin (La Roche-surYon), Delphine Colling (Roubaix), Alexandre Conia (Chartres), Rémi Coudroy (Poitiers), Martin Cour (Lyon), Damien Contou (Argenteuil), Fabrice Daviaud (Corbeil-Essonnes), Vincent Das (Montreuil), Jean Dellamonica (Nice), Nadège Demars (Antoine Beclère, AP-HP), Stephan Ehrmann (Tours), Arnaud Galbois (Quincy sous Sénart), Elodie Gelisse (Reims), Julien Grouille (Blois), Laurent Guérin (Ambroise Paré-AP-HP), Emmanuel Guérot (HEGP, AP-HP), Samir Jaber (Montpellier), Caroline Jannière (Créteil), Sébastien Jochmans (Melun), Mathieu Jozwiak (Kremlin Bicêtre, AP-HP), Pierre Kalfon (Chartres), Antoine Kimmoun (Nancy), Alexandre Lautrette (Clermont Ferrand), Jérémie Lemarié (Nancy), Charlène Le Moal (Le Mans), Christophe Lenclud (Mantes La Jolie), Nicolas Lerolle (Angers), Olivier Leroy (Tourcoing), Antoine Marchalot (Dieppe), Bruno Mégarbane (Lariboisière, AP-HP), Etienne de Montmollin (Saint-Denis), Frédéric Pène (Cochin, AP-HP), Claire Pichereau (Poissy), Gaëtan Plantefève (Argenteuil), Sébastien Préau (Lille), Gabriel Preda (Saint-Antoine, AP-HP), Nicolas de Prost (Henri Mondor, AP-HP), Jean-Pierre Quenot (Dijon), Sylvie Ricome (Aulnay-sous-Bois), Damien Roux (Louis Mourier, AP-HP), Bertrand Sauneuf 
(Cherbourg), Matthieu Schmidt (Pitié Salpêtrière, AP-HP), Guillaume Schnell (Le Havre), Romain Sonneville (Bichat, AP-HP), Jean-Marc Tadié (Rennes), Yacine Tandjaoui (Avicenne, AP-HP), Martial Tchir (Villeneuve Saint Georges), Nicolas Terzi (Grenoble), Xavier Valette (Caen), Lara Zafrani (Saint-Louis, AP-HP), Benjamin Zuber (Versailles).

\section{Funding}

This study received a financial support of the Fondation de France (\#0069110).

\section{Compliance with ethical standards}

\section{Conflicts of interest}

The authors have not disclosed any potential conflict of interest.

\section{References}

1. Contou D, Sonneville R, Canoui-Poitrine F et al (2018) Clinical spectrum and short-term outcome of adult patients with purpura fulminans: a French multicenter retrospective cohort study. Intensive Care Med 44:1502-1511. https://doi.org/10.1007/s00134-018-5341-3

2. Giraud T, Dhainaut JF, Schremmer B et al (1991) Adult overwhelming meningococcal purpura: a study of 35 cases, 1977-1989. Arch Intern Med 151:310-316

3. Contou D, Canoui-Poitrine F, Coudroy R et al (2018) Long-term quality of life in adult patients surviving purpura fulminans: an exposed-unexposed multicenter cohort study. Clin Infect Dis 69(2):332-340. https://doi. org/10.1093/cid/ciy901

4. Staquet P, Lemee L, Verdier E et al (2007) Detection of Neisseria meningitidis DNA from skin lesion biopsy using real-time PCR: usefulness in the aetiological diagnosis of purpura fulminans. Intensive Care Med 33:1168-1172. https://doi.org/10.1007/s00134-007-0667-2

5. Venkatesan A, Tunkel AR, Bloch KC et al (2013) Case definitions, diagnostic algorithms, and priorities in encephalitis: consensus statement of the international encephalitis consortium. Clin Infect Dis 57:1114-1128. https ://doi.org/10.1093/cid/cit458 